\title{
The Relationship between Teachers' Democratic Classroom Management Attitudes and Students' Critical Thinking Dispositions
}

\author{
Tuğba Turabik ${ }^{1}$, Feyza Gün ${ }^{1}$ \\ ${ }^{1}$ Research Assistant, Faculty of Education, Hacettepe University, Ankara, Turkey \\ Correspondence: Tuğba Turabik, Faculty of Education, Hacettepe University, Beytepe, Ankara, 06800, Turkey.
}

Received: September 27, 2016

Accepted: October 10, 2016

Online Published: October 28, 2016

doi:10.11114/jets.v4i12.1901

URL: http://dx.doi.org/10.11114/jets.v4i12.1901

\begin{abstract}
This study aimed to investigate the relationship between democratic classroom management attitudes of teachers and critical thinking dispositions of students. The study group consisted of 530 students from public high schools located in Altındağ district of the province of Ankara. The data was collected with the use of "Democratic Classroom Management Scale" developed by Demirtaş (2004) and "Critical Thinking Dispositions Inventory" developed by Akbıyık (2002) during the spring term of 2013-2014 academic year. The data were analyzed by conducting $t$ test, ANOVA, Pearson correlation and simple linear regression analysis. In the study it was observed that students' views about teachers' democratic classroom management attitudes were at moderate level and their critical thinking dispositions were at high level. Furthermore, it was concluded that students' views regarding teachers' democratic classroom management attitudes and their critical thinking varied according to different variables. In the study, it was found that there was a low, positive and statistically significant relationship between the democratic classroom management attitudes of teachers and the critical thinking disposition of students. In addition, it was also founded that democratic classroom management attitudes of teachers was a significant predictor of the critical thinking disposition of students.
\end{abstract}

Keywords: democratic classroom management, critical thinking dispositions, student, high school, simple linear regression

\section{Introduction}

Individuals have to keep making decisions, solving problems and get a large variety of information throughout their lives. In this regard, while making decisions, individuals have to adopt a critical way of thinking in order to make the best choices, find the best and most economic solutions to their problems, and acquire scientific knowledge in a selective way. Society also needs this way of thinking as much as individuals. Because, it does not seem likely to expect a society, individuals of which do not think, to develop. Offering individuals an appropriate environment for thinking, and providing opportunities to express their ideas without any kind of hesitation are as much important as the necessity of individuals and expressing their ideas. In this context, schools where individuals spend a significant part of their lives starting from early childhood, and teachers who work there are supposed to undertake important roles. In fact, teachers are expected to encourage their students to think, and adopt a democratic class management attitude to make students feel free to express their ideas.

Leblanc and Skarrupa (1997) stated that democratic classes enhance emotional intelligence, increase capability of students to handle problems from different aspects and improve their social talents related to conflict solution such as compromising and arbitration. In parallel with this, Campbell (2009, p. 239) mentions that, students are given opportunity to reflect their values to education program and they are taught critical thinking in schools adopting values and principles of democracy. Similarly, Kocoska (2009) also drew attention to the relationship between teachers' democratic classroom management attitudes and students' critical thinking. She stated that democratic classes help students be curios, analyze thoughts, determine goals, access studies, seek for alternatives, defend their thoughts reasonably and be open to new ideas, which altogether mean critical thinking. With reference to these views, in this study it was aimed to investigate the relationship between teachers' democratic classroom management and students' critical thinking disposition.

\subsection{Democratic Classroom Management}

Besides the formal education given in schools, informal education students attend involuntary has also an important role. 
One of the significant factors within the scope of informal education is teacher behaviors and attitudes. It is possible to say that these positive or negative behaviors and attitudes influence students in various ways (Assor, Kaplan, Kanat-Maymon \& Roth, 2005; Esquivel, 1995; Gorham \& Christophel, 1992; Wright \& Nuthall, 1970). Therefore, for an efficient education-training, teachers are expected to display positive attitudes and behaviors. One of these attitudes is the democratic classroom management that provides free learning atmosphere for students.

In the studies conducted since 1930s, the effects of different management types have been observed. For instance, Lewin (1939), reviewed the effects of behaviors of leaders in three types as autocratic, releaser and democratic on the process of presenting product of students. The students working with autocratic leader worked only in the existence of the leader and by obeying him. The number of the product they have presented has become tremendous but in low quality. The students working with the releaser leader have presented few but unqualified products. When the leader left the students, chaos predominated. The students working with democratic leader worked even in the absence of the leader with high motivation and presented high-qualified products. In the study which was conducted with students, Deci (1996; as cited in Hashimoto \& Fukuda, 2011) wanted them to make jigsaw puzzle. An alternative was presented for a jigsaw puzzle for the first group and no time limit was put. Only one jigsaw puzzle was given to the second group and a time limit was put. The students in the first group were determined to be more satisfied with what they have done than the second group. The reason was associated with the motivation of the students who were given the opportunity to select. As can be understood from the studies mentioned, the prevalence of democratic management manner raises the inner motivations of students, makes them free in class atmosphere and enables the effective running of the education-training activities.

The principles of democracy, which is not only a state government manner but also a lifestyle (Dewey, 1991), are also related to common decision making mechanisms in any organization (Beetham \& Boyle, 1998). Democracy, at the same time, is a concept covering concepts such as equity, justice, freedom, sovereignty of mind, respect to human being, and etc. (Büyükdüvenci, 1990). Wraga (1998) explained the principles of democracy and their application to classes as follows (1) Sovereignty of Public: Teachers give opportunity to students to involve in decisions such as classroom rules that affect themselves. (2) Freedom: In democratic classrooms, which are the model of the freedom of the mind, the ideas of the students are given importance and students are given responsibility to search for problematic situations that require decision-making in a disciplined way. (3) Equity: In democratic classrooms, each student has the right to be behaved equally and fairly and participate in classroom discussions and group decisions. Teachers show effort for each student to learn in the best way. (4) Individualism: Classroom atmosphere is arranged in a way to support and develop the self-control, self-discipline and self-orientation behaviors of students. In the education process, interests of students are taken into consideration. Classroom atmosphere is open to all kinds of political and moral values. Students are free to explain or not to explain their opinions. Most importantly, students are protected from propaganda and inspirations through learning critical thinking. (5) Social responsibility: taking part in the process of making classroom decisions or solving problems increase the social responsibilities of the students. Students learn how to act in group environment, how to use parliamentarian processes and handle social actions beyond school and classroom. Considering the values and principles of democracy, it is possible to say that the teachers who adopt democratic classroom management attitude have laid the foundations of a free education atmosphere, being aware of the fact that each student is equal, creating a fair atmosphere for students, listening to their opinions without judging, enabling them recognize the value and respect shown for their ideas.

Pryor (2004) stated that teachers will ensure an atmosphere in which students have freethinking opportunities and understand the characteristics of democracy and they should prompt three themes regarding democracy to achieve this. She listed these three themes as freedom and independence, justice and rightness, and equity and equal possibilities. Things that need to be done to practice these themes are as follows:

Freedom and independence

- Classroom rules should be determined in cooperation with students, parents and school principals.

- Classroom meetings should be held.

Justice and rightness

- Whether the methods which are used in grading are fair or not should be determined.

- Students should be given the opportunity for self-evaluation

Independence and equity

- Students' needs should be considered in classroom activities and special / gifted children should be given educational opportunities regarding their needs. 
- All students should be treated fairly to benefit from the opportunities

In accordance with this, it can be thought that democratic classroom atmosphere established with the activation of freedom and independence, justice and rightness, equity and equal opportunities can be useful for students.

\subsection{Critical Thinking}

The changes experienced in information and communication technologies towards the end of the twentieth century require individuals to develop data processing skills as it will help them adapt to these changes such as literacy, capability of making mathematical operation, problem solving, and etc. as well as the general skills such as interpersonal relations, self-governance and ability of learning, and etc. (OECD, 2013). These skills, cited as 21th century skills, were grouped by Trilling and Fadel (2009, p. xxvi) as follows: (1) Learning and innovation skills: critical thinking and problem solving, communication and cooperation, creativity and innovation. (2) Digital literacy: information literacy, media literacy, information and communication technologies literacy. (3) Career and life skills: flexibility and compliance, ability of taking initiative and self-governance, social and cross-cultural interaction, reproductivity and accountability, leadership and responsibility. As can be understood from the literature, critical thinking skills have important roles in the development of individuals and thus that of countries (Ananiadou \& Claro, 2009; Bellanca \& Brandt, 2010; Salpeter, 2003). Educational institutions and teachers bear the main responsibility for training individuals with such important skills. It is critically important that teachers form classroom environments that will promote the critical thinking skills of students.

Critical thinking was studied by famous Greek philosophers such as Socrates, Aristoteles and Platon 2500 years ago, and was defined as logical and reflective thinking focused on the necessity of what to do or what to believe by Ennis (1985). Glaser (1985) defined critical thinking as the knowledge of logical reasoning methods and the attitude towards thinking carefully on various situations and problems that emerge as a result of the experiences of a person and the skills of applying these knowledge. Lipman (1988), who emphasized that critical thinking is sensitive to conditions, based on the criteria and has a structure correcting itself, stated that owing to these features allow making useful evaluations. When other definitions in the literature are taken into consideration, under certain criteria, it is possible to define critical thinking as mental processes, strategies and descriptions that are used in problem solving and making decisions and logical reasoning of opinions, knowledge (Beyer, 1985; Sternberg, 1986; Scriven \& Paul, 2004). Paul and Elder, who described critical thinking as an art of analysis and evaluation to improving thinking $(2007$, p. 4) listed the features that an individual of good critical thinkers has got as follows: They determine quite important problems and formulate these clearly and completely, compile and analyze related information in order to make adequate comment through the use of abstract opinions, offer well-reasoned results and solutions that they test in accordance with the relevant standards and criteria, and they think in an open minded way with the alternative ways of thinking which they predicted and evaluated their assumptions, their possible outcomes and results in practice. According to Nickerson (1987), the characteristics of critical thinkers are as follows (as cited in Schafersman, 1991):

- They use evidences objectively and skillfully

- They organize thoughts, express them in short, abstract and consistently

- Distinguish reasonable and unreasonable assumptions

- Delay making deductions in case of lack of evidence to support a decision

- Understand the difference between reasoning and rationalizing

- Try to predict the possible results of alternative actions

- $\quad$ See indistinct similarities

- Can learn independently and are always interested in learning in this manner

- Apply problem solving techniques on the subjects except they have learnt

- Clear irrelevance in an argument, and express it with appropriate terms.

- Question the opinions of a person and the assumptions and inferences of these opinions as a habit.

- Knows that a people could be mistaken in their opinions, these opinions may only be prejudicial assumptions and giving weight to the evidences based on personal preferences can be dangerous.

Critical thinking is deemed as important for the individualization that means generating correct solutions, making right decisions, thinking independently, being free and original individual and for being citizen that means being sensitive for social problems, having his/her own opinions apart from dogmatic thoughts, the capability of evaluating consistency, durability of his/her own and others' opinions, having empathy and discussion, having compromising culture (Gürkaynak, Üstel \& Gülgöz, 2008). Thanks to these features, the individuals who think critically will struggle on the 
way of seeking the most reasonable one by questioning each issue concerning them or the society. It is possible to say that this situation will lead to an improvement both for the individuals and society. Beyer (1985) also pointed out that individuals should have the ability of critical thinking for making correct decisions on the issues related to personal, social, economic, political and citizenship matters in order to catch up with the accelerated change in the world and to maintain democracy successfully.

It is possible to say that critical thinking has a positive effect on students to improve their academic success with the features they have. Besides, student-centered education described as a teaching approach which is expected to be adopted by all educational institutions nowadays and suggests active learning of student in cooperation with individuals and group instead of straight narration of teacher and in which the student is responsible for his/her own improvement (Nanney, 2004) is also based on the way that students seek for information and configures it on their own. The studies on the relationship between critical thinking and academic success indicate a positive relation between these two concepts (Karbalaei, 2012; Lee, 2015; Semerci, 2011; Villavicencio, 2011).

It is stated that critical thinking, one of the major abilities in 21 st century, is significant in terms of providing opportunity to analyze and evaluate claims and evidences independent from prejudices and former knowledge. (Noone, Bunting \& Hogan, 2016). It can be said that critical thinking has many benefits for individuals and thus the society in terms of raising awareness to separate the dogmas from scientific knowledge. On the other hand, the democratic classroom management attitude which provides formation of democratic environment on classroom basis, is important as an experience helping individuals adopt democracy starting from early ages. Therefore, it is important to analyze these concepts. In the literature, it is seen that many researches have been carried out in various stages on critical thinking and democratic classroom management from elementary school to post graduate education (Ten Dam \& Volman, 2004; Demirkaya, 2008; Emir, 2012; Glaser, 1985; Karadüz, 2010; Kesici, 2008; Kurt \& Kürüm, 2010; Korkmaz \& Yeşil, 2009; Özdemir, 2005; Paul, 1984; Rainer \& Guyton, 1999; Şentürk \& Oyman, 2014). However, any studies questioning the relationship between critical thinking disposition and democratic class management attitudes have been found. Therefore, this study is expected to make positive contributions in this field. For this purpose, answers were sought to the following questions:

1. What is the level of students' critical thinking dispositions and their views about the democratic classroom management attitude of their teachers?

2. How do students' views about democratic classroom management attitude of teachers and their critical thinking dispositions vary according to their gender, their grade, monthly income of their families and educational background of their parents'?

3. To what extent are the relationship between students' opinions about democratic classroom management behaviors of teachers and their critical dispositions related?

4. To what extent do students' opinions about democratic classroom management attitudes of teachers explain the variance of their critical thinking dispositions?

\section{Method}

In this research, the relational scanning model was adopted to discuss the relation between democratic class management attitudes and critical thinking dispositions of students. The data obtained in this regard was analyzed by using quantitative techniques.

\subsection{Working Group}

The working group of the study consists of 530 high school students registered at the schools located in Altındağ county of Ankara. 311 (\%58.7) of the participant students are female, and $219(\% 41.3)$ are male. 177 (\%33.4) students study at 9th grade, $170(\% 32.1)$ at 10 th grade, $134(\% 25.3)$ at 11 th grade and $49(\% 9.2)$ at 12 th grade.

\subsection{Data Collection Tools}

In the study, "Democratic Classroom Management Scale (DCMS)" developed by Demirtaş (2004) was used in order to evaluate students' perceptions regarding democratic class management attitudes. DCMS is a five degree Likert type scale which includes values between "never" and "always". Items included in the scale are as follows: "Do you think your teacher makes discrimination among the students in classroom?" and "Do you express your personal thoughts on subjects freely in classroom environment?" Cronbach alpha coefficient of the scale was determined as .76 by Demirtaş (2004). Cronbach alpha coefficient of the whole scale was recalculated as .93 in this study, and found to be reliable. The acceptability evaluations of the scale were performed by means of Confirmatory Factor Analysis (CFA). The results of the goodness of fit calculated by means of CFA analysis were obtained as follows: $\left[\mathrm{X}^{2}=899.85 ; \mathrm{sd}=275 ; \mathrm{X}^{2} / \mathrm{sd}=3.27\right.$; $\mathrm{AGFI}=.86 ; \mathrm{GFI}=.88 ; \mathrm{NFI}=.97 ; \mathrm{CFI}=.98 ; \mathrm{IFI}=.98 ; \mathrm{RMR}=.074$ and $\mathrm{RMSEA}=.066]$. Byrne and Campbell $(1999)$ 
indicated that acceptable fit values of goodness of fit indexes of are 90 and above for AGFI, GFI, NFI, CFI, IFI, and 0.08 and below for RMR and RMSEA. The results of the goodness of fit obtained by this means revealed that DCMS is an acceptable tool to be used in this study.

In order to determine the critical thinking dispositions of the students, Critical Thinking Disposition Scale (CTDS) developed by Akbiyık (2002) was used in this study. CTDS is a five degree Likert type scale which includes values between "totally agree" and "totally disagree". The scale comprising of 30 items has a single dimensioned structure. The items included in the scale were: "I try to understand the viewpoints of people towards matters." and "I try to consider all aspects of a matter to make right decisions". The cronbach alpha coefficient of the scale was calculated as .87 by Akbiyık (2002). The cronbach alpha value for this study was calculated as .83 and the scale was determined to be reliable. The confirmatory factor analysis (CFA) was carried out in order to evaluate the structural acceptability of the scale. The goodness of fit values calculated in accordance with CFA results were as follows: $\left[\mathrm{X}^{2}=1122.26\right.$; sd $=$ $402 ; \mathrm{X}^{2} / \mathrm{sd}=2.79 ; \mathrm{AGFI}=.86 ; \mathrm{GFI}=.88 ; \mathrm{NFI}=.96 ; \mathrm{CFI}=.97 ; \mathrm{IFI}=.97 ; \mathrm{RMR}=.072$ and RMSEA $\left.=.058\right]$. According to Kline (2005), the ratio of chi square value to degree of freedom should be lower than 0.05. Hu and Bentler (1999) state that RMSEA value below 0.08 points good fitness and being below 0.05 refer to very good fitness. According to this, results of goodness of fit obtained in the study confirmed the single factor structure of CTDS.

\subsection{Data Analysis}

Data set was subjected to preliminary analysis and no problem was encountered in terms of distribution, homogeneity and linearity. In order to determine the reliability of the scales used within the scope of this research, the internal consistency coefficients of Cronbach alpha were calculated. The structural acceptability of data collection tools was tested with confirmatory factor analysis on LISREL 8.8 software. The data obtained in the research were analyzed with arithmetical mean, standard deviation, frequency, percentage, $t$-test, unidirectional variance analysis (ANOVA), Pearson correlation coefficient and simple linear regression analysis. For $F$ value found significant, LSD test was used to designate source of difference and significance tests were carried out at 0.05 level.

These analyses were conducted with the SPSS 22.0 version. The arithmetical means were interpreted as follows: intervals $1.00-1.79$ was assessed as very low, $1.80-2.59$ as low, $2.60-3.39$ as medium, $3.40-4.19$ as high, 4.20-5.00 as quite high. These intervals were obtained by dividing the width of series between points as follows, the highest " 5 " and the lowest "1" given scale items into the number of the option.

\section{Results}

Mean and standard deviation points regarding students' views about democratic classroom management attitudes of teachers and their critical thinking dispositions as well as the Pearson correlation coefficient calculations which were performed to determine the relationship between these two variables are given at Table 1.

Table 1. Pearson correlation matrix regarding the relationship between students' views about teachers' democratic classroom management attitudes and their critical thinking dispositions, and mean and standard deviation values of the scales

\begin{tabular}{rlrlll} 
& \multicolumn{1}{c}{ Scale } & $X$ & $d$ & 1 & 2 \\
\cline { 2 - 6 } & 1.DCMS & 3.18 & .75 & - & $.264^{* * *}$ \\
\cline { 2 - 5 } & 2.CTDS & 3.65 & .48 & $.264^{* *}$ & - \\
\cline { 2 - 5 } & & & & &
\end{tabular}

The mean of students' views about democratic classroom management attitudes of their teachers is 3.18 as can be seen at Table 1. The mean of critical thinking dispositions of students is 3.65. Accordingly, while the views of the students about democratic classroom management attitudes of their teachers are at medium level, their critical thinking dispositions are at high level. It is also observed that the relation between democratic classroom management and their critical thinking dispositions were found to be significant, positive and at a low level $\left(\mathrm{r}_{\mathrm{dcms} \times c t d s}=.26 ; p<.01\right)$.

Table 2. $t$-test results regarding students' views about teachers' democratic classroom management attitudes and their critical thinking dispositions with respect to gender variable

\begin{tabular}{|c|c|c|c|c|c|c|}
\hline Scale & Gender & $\mathrm{N}$ & $X$ & $s d$ & $t$ & $p$ \\
\hline \multirow{2}{*}{$\overline{\mathrm{DCMS}}$} & Female & 311 & 3.22 & .72 & \multirow[t]{2}{*}{1.36} & \multirow[t]{2}{*}{.174} \\
\hline & Male & 219 & 3.13 & .80 & & \\
\hline \multirow[t]{2}{*}{ CTDS } & Female & 311 & 3.73 & .44 & \multirow[t]{2}{*}{4.226} & \multirow[t]{2}{*}{.000} \\
\hline & Male & 219 & 3.55 & .51 & & \\
\hline
\end{tabular}

${ }^{*} p<.05$

The participants were subjected to t-test in order to determine whether their views on democratic classroom management attitudes and critical thinking dispositions vary depending on their gender. $t$-test results for gender variable are given in Table 2 . 
As it can also be seen from Table 2, the views of female $(\bar{X}=3.22)$ and male $(\bar{X}=3.13)$ students about democratic classroom management attitudes of teachers are at moderate level, which shows no statistically significant difference according to gender variable. $\left(t_{(528)}=1.36, p>.05\right)$. This finding reveals that the views of male and female students about the democratic classroom management attitudes of their teachers are at similar level. However, it is understood that the critical thinking dispositions of female $(\bar{X}=3.73)$ and male $(\bar{X}=3.55)$ students are at high level and the critical thinking dispositions of students show statistically significant difference depending on gender variable $\left(t_{(528)}=4.226, p\right.$ $<.05)$. According to this, the critical thinking dispositions of female students are relatively higher than that of male students.

ANOVA was carried out in order to detect whether the views of students about democratic classroom management attitude of their teachers and their critical thinking dispositions display significant difference according to grade levels. ANOVA results for grade level variables and the results of LSD carried out to determine the source of difference are presented in Table 3.

Table 3. ANOVA results of the students' views about teachers' democratic classroom management attitudes and their critical thinking dispositions with respect to the grade variable

\begin{tabular}{|c|c|c|c|c|c|c|c|}
\hline Scale & Grade & $\mathrm{N}$ & $\bar{X}$ & $s d$ & $F$ & $p$ & Significant difference \\
\hline \multirow[t]{4}{*}{ DCMS } & 9th grade & 177 & 3.49 & .73 & 24.906 & $.000^{*}$ & 9th - 10th grade \\
\hline & 10th grade & 170 & 3.21 & .71 & & & 9th -11 th grade \\
\hline & 11 th grade & 134 & 2.90 & .66 & & & 9 th -12 th grade \\
\hline & 12 th grade & 49 & 2.74 & .76 & & & $\begin{array}{l}10 \text { th }-11 \text { th grade } \\
10 \text { th }-12 \text { th grade }\end{array}$ \\
\hline \multirow[t]{4}{*}{ CTDS } & 9th grade & 177 & 3.69 & .47 & 1.549 & .201 & \\
\hline & 10th grade & 170 & 3.67 & .47 & & & \\
\hline & 10th grade & 134 & 3.58 & .47 & & & - \\
\hline & 10th grade & 49 & 3.70 & .53 & & & \\
\hline
\end{tabular}

${ }^{*} p<.05$

As shown in Table 3, there is a statistically significant difference is observed for views of students about democratic classroom management attitude of their teachers according to grade variable $\left(F_{(3-526)}=24.906, p<.05\right)$. Based on the results of LSD test carried out to determine the source of the difference, the statistically significant difference is determined between 9th grade $(\bar{X}=3.49)$ and 10th grade $(\bar{X}=3.21)$, 9th grade and 11th grade $(\bar{X}=2.90)$, 9th grade and 12 th grade $(\bar{X}=2.74), 10$ th grade and 11th grade and finally 10 th grade and 12 th grade. The 9 th graders views about the democratic classroom management attitudes of their teachers are relatively higher than that of 10th, 11th and 12th graders. 10th grade students' views about the democratic classroom management attitudes of their teachers are relatively higher than that of 11th, and 12th grade students. However no statistically significant difference was found for critical thinking dispositions of students according to grade variable. $\left(F_{(3-526)}=1.549, p>.05\right)$. The critical thinking dispositions of 9th grade $(\bar{X}=3.69)$, 10th grade $(\bar{X}=3.67)$, 11th grade $(\bar{X}=3.58)$ and 12th grade $(\bar{X}=3.70)$ students are at high level and similar.

The views of the students about the democratic classroom management attitudes of their teachers and their critical thinking dispositions are analyzed with ANOVA according to the monthly income of their parents. Table 4 shows the results of the LSD test made to display the source of the difference and ANOVA results according to monthly income of participants' families.

Table 4. ANOVA results of the students' views about teachers' democratic classroom management attitudes and their critical thinking dispositions with respect to the monthly income of their parents

\begin{tabular}{llllllll}
\hline Scale & Monthly income & $\mathrm{N}$ & $\bar{X}$ & $s d$ & $F$ & $p$ & Significant difference $^{*}$ \\
\hline DCMS & 1500 TL and less & 135 & 3.30 & .70 & 3.906 & $.009^{*}$ & 1500 TL and less - 2501 \\
& 1501 - 2500 TL & 193 & 3.24 & .79 & & & TL - 3500 TL \\
& 2501 TL - 3500 TL & 115 & 3.10 & .72 & & 1500 TL and less - 3501 \\
& 3501 TL and over & 87 & 2.98 & .77 & & TL and over \\
& & & & & & 1501 TL-2500 TL - \\
\hline CTDS & 1500 TL and less & 135 & 3.74 & .44 & 5.038 & $.002^{*}$ & 3501 TL and over \\
& 1501 - 2500 TL & 193 & 3.70 & .50 & & & TL - 3500 TL TL and less - 2501 \\
& 2501 TL - 3500 TL & 115 & 3.57 & .44 & & & 1500 TL and less - 3501 \\
& 3501 TL and over & 87 & 3.53 & .50 & & TL and over \\
& & & & & & 1501 TL-2500 TL - 2501 \\
& & & & & & TL-3500 TL \\
& & & & & & 1501 TL-2500 TL - 3501 \\
& & & & & &
\end{tabular}

${ }^{*} p<.05$ 
As can be seen in Table 4, there is a statistically significant difference with regard to views of the students about the democratic classroom management attitude of their teachers according to the monthly income level of ther families ( $F$ $(3-526)=3.906, p<.05)$. According to the results of LSD test carried out to determine the source of difference, it is seen that the means of the students whose family income is $1500 \mathrm{TL}$ and less $(\bar{X}=3.30)$ turn out higher compared to the students whose family income is between $2501 \mathrm{TL}-3500 \mathrm{TL}(\bar{X}=3.10)$ and the ones whose family income is $3501 \mathrm{TL}$ and over $(\bar{X}=2.98)$. A significant difference was also observed between the students whose family income is $1501 \mathrm{TL}$ $2500 \mathrm{TL}(\bar{X}=3.24)$ and the students whose family income is $3501 \mathrm{TL}$ and above $(\bar{X}=2.98)$. The criticial thinking dispositions of students have shown a statistically significant difference depending on the monthly income of family variable as well $\left(F_{(3-526)}=5.038, p<.05\right)$. According to LSD test results, a significant difference is determined between the students whose monthly family income is $1500 \mathrm{TL}$ and less $(\bar{X}=3.74)$ and the students whose monthly family income is $3501 \mathrm{TL}$ and above $(\bar{X}=3.53)$. Similarly, the existence of the significant difference between the students whose monthly family income is $1501 \mathrm{TL}-2500 \mathrm{TL}(\bar{X}=3.70)$ and the students whose monthly family income is 2501 $\mathrm{TL}-3500 \mathrm{TL}$ and 3501 and above was reported. Both views about the democratic classroom management attitude of their teachers and the critical thinking dispositions of the students whose families have lower monthly income are relatively higher than their counterparts whose family incomes are higher.

ANOVA was carried out in order to determine whether the views of the students about the democratic classroom management attitudes of their teachers and their critical thinking dispositions vary according to the educational background of fathers. Table 5 shows the ANOVA results and the results of LSD test carried out to determine the source of the difference with respect to the educational background of fathers.

Table 5. ANOVA results of the students' views about teachers' democratic classroom management attitudes and their critical thinking dispositions with respect to fathers' education level

\begin{tabular}{|c|c|c|c|c|c|c|c|}
\hline Scale & Fathers' education level & $\mathrm{N}$ & $\bar{X}$ & $s d$ & $F$ & $p$ & Significant difference \\
\hline \multirow[t]{4}{*}{ DCMS } & Elementary school and lower & 96 & 3.30 & .78 & \multirow[t]{4}{*}{4.074} & \multirow[t]{4}{*}{$.007^{*}$} & Elementary school and \\
\hline & Secondary school & 95 & 3.33 & .74 & & & lower - associate degree \\
\hline & High school & 175 & 3.19 & .76 & & & and above \\
\hline & Associate degree and above & 164 & 3.03 & .73 & & & $\begin{array}{l}\text { Secondary school } \\
\text { associate degree and above }\end{array}$ \\
\hline \multirow[t]{4}{*}{ CTDS } & Elementary school and lower & 96 & 3.68 & .54 & \multirow[t]{4}{*}{1.235} & \multirow[t]{4}{*}{.296} & \\
\hline & Secondary school & 95 & 3.67 & .45 & & & \\
\hline & High school & 175 & 3.69 & .47 & & & 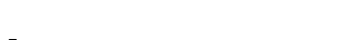 \\
\hline & Associate degree and above & 164 & 3.59 & .46 & & & - \\
\hline
\end{tabular}

As can be seen in Table 5, a statistically significant difference is observed in the views of the students about democratic classroom management attitude according to education level of father variable $\left(F_{(3-526)}=4.074, p<.05\right)$. As for that, the results of the LSD test carries out to specify the source of the difference, there are statistically significant differences among the education level of associate degree and above $(\bar{X}=3.03)$ and education level of elementary school and lower $(\bar{X}=3,30)$ and education level of secondary school $(\bar{X}=3.33)$ according to the fathers' education level. The critical thinking dispositions of students have shown no significant difference according to the education level of father variable $\left(F_{(3-526)}=1.235, p>.05\right)$.

ANOVA was carried out to see whether the critical thinking dispositions of the students and their views about the democratic classroom management attitudes of teachers demonstrate a significant difference depending on the education level of students' mothers. In Table 6, ANOVA results and the conclusions of LSD carried out to determine the source of the difference are given according to the education level of mothers.

Table 6. ANOVA results of the students' views about teachers' democratic classroom management attitudes and their critical thinking dispositions with respect to the mothers' education level

\begin{tabular}{|c|c|c|c|c|c|c|c|}
\hline Scale & Mothers' education level & $\mathrm{N}$ & $\bar{X}$ & $s d$ & $F$ & $p$ & Significant difference ${ }^{*}$ \\
\hline \multirow[t]{6}{*}{ DCMS } & Elementary school and lower & 192 & 3.27 & .75 & 4.330 & .005 & Elementary school and \\
\hline & Secondary school & 87 & 3.21 & .75 & & & lower - associate degree \\
\hline & High school & 170 & 3.20 & .77 & & & and above \\
\hline & Associate degree and above & 81 & 2.92 & .68 & & & Secondary school - \\
\hline & & & & & & & associate degree and above \\
\hline & & & & & & & High school- associate \\
\hline \multirow{4}{*}{ CTDS } & Elementary school and lower & 192 & 369 & 48 & 2539 & 056 & \\
\hline & Secondary school & 87 & 3.73 & .49 & & & \\
\hline & High school & 170 & 3.63 & .47 & & & - \\
\hline & Associate degree and above & 81 & 3.55 & .45 & & & \\
\hline
\end{tabular}

${ }^{*} p<.05$ 
As can be monitored from Table 6, there is a statistically significant difference in the views of the students about the democratic classroom management attitude of teachers according education level of students' mothers $\left(F_{(3-526)}=4.330\right.$, $p<.05)$. According to the results of the LSD test carried out to determine the source of the difference, there are statistical significant differences among the students whose mothers have associate degree and above $(\bar{X}=2.92)$, the students whose mothers have elementary school and lower education level $(\bar{X}=3.27)$, the students whose mothers are secondary school graduates $(\bar{X}=3.21)$ and high school graduates $(\bar{X}=3.20)$. In the light of these findings, it seems that the views about the democratic classroom management of teachers of the students whose mothers have associate degree and higher are lower than that of the students whose mothers have lower degrees. Moreover, as can be seen in Table 6, no statistical difference was found for the critical thinking dispositions of the students according to the education level of their mothers $\left(F_{(3-526)}=2.539, p>.05\right)$.

Table 7 displays the results of the simple linear regression analysis conducted to determine the regression power of critical thinking disposition for democratic classroom management attitude.

Table 7. The results of the simple linear regression regarding the students' critical dispositions by their views about teachers' democratic classroom management

\begin{tabular}{lllllll} 
& Variable & $\mathrm{B}$ & Standard error & $\beta$ & $t$ & $p^{*}$ \\
\cline { 2 - 7 } & Constant & 3.12 & .087 & - & 35.90 & .000 \\
\cline { 2 - 7 } & Democratic classroom management & .167 & .027 & .26 & 6.28 & .000 \\
\cline { 2 - 7 } & $\mathrm{R}=0.26$ & $\mathrm{R}^{2}=0.07$ & \multicolumn{5}{c}{$F_{(1-528)}=39.441$} & $p=.000$ & \\
\cline { 2 - 7 }
\end{tabular}

As can be seen from Table 7, it is observed that there is a low level significant relationship between the views of the students about the democratic classroom management attitudes of their teachers and their critical thinking dispositions $\left(\mathrm{R}=.26 ; \mathrm{R}^{2}=.07 ; p<.01\right)$. However, it was observed that the views of the students about the democratic classroom management counts for $7 \%$ of the variance in their critical thinking dispositions. When the results of $t$ test regarding the significance of regression coefficients were examined, it was confirmed that the perception of democratic grade management is a meaningful predictor of the critical thinking dispositions of students.

\section{Conclusion and Discussion}

In this study, primarily, the views of the students about democratic classroom management attitudes and their critical thinking dispositions were examined. The findings indicate that the views of the students about the democratic classroom management attitudes of their teachers are at moderate level. In a similar study carried out by Yalçın (2007, p. 103), it was detected that high school students do not find classroom management attitudes of their teachers democratic. In some studies similar to this study question the democracy attitudes of instructors according to the opinions of students, it was seen that participants perceive the attitudes of instructors democratic at moderate level (Demirtaş, 2004; Duman \& Koç, 2004). In their studies conducted related to student- teacher relation, Balay, Kaya and Doğu (2012) found that the views of the students about the type of democratic relationship are at moderate level. These findings state that democratic attitudes in classroom management approaches and the attitudes of educators are insufficient.

Another finding of the search is that male and female students' views about the democratic classroom management attitude of their teachers are moderate and do not differ according to gender. From this output, it is understood that the male and female views of the students about the democratic classroom management attitudes of their teachers are similar. It is possible to come across such studies supporting this finding in the literature. For instance, in similar studies conducted in universities, no significant difference is found in the views of the students about the democratic classroom management attitudes of instructors (Demirtaş, 2004; Erdem \& Sarıtaş, 2006; Ergün \& Kamer, 2009). In the study conducted regarding student - teacher relation, Balay et al. (2012) deduced that no difference exists in democratic relation type according to gender. However, in the studies carried out in general high schools by Yalçın (2007, p. 104) and in universities performed by Kaya, Taşdan, Top and Metin (2012), female students find teachers and instructors more democratic compared to male students.

However, in this study, it was found that the views about the democratic classroom management vary depending on classroom level, monthly income of the family, education level of fathers and mothers. According to this, while the views of the students at 9th grade is at a high level, the views of the students at 10th, 11th and 12th grade are at moderate level. The views of the students at 9th grade are at a higher level than the students at 10th, 11th and 12th grade and the views of the students at 10th grade are higher than that of the students in 11th and 12th grade. To be more precise, as grade level rises, students participate less to the opinion about that teachers have democratic classroom management attitude. There are researches supporting this finding in the literature (Balay et al. 2012; Erdem \& Sarıtaş, 2006; Kaya et al. 2012). Yalçın-Durmuş and Demirtaş (2009) explained the reason of this with the fact that lower grade do not know all teachers yet, obey school rules more, do not conflict with teachers because of their age and do not get 
over from the atmosphere of elementary school. Contrary to this finding, Ergün and Kamer (2009) found that in comparison with 3th and 4th grade undergraduate students, 1 th and 2 th grade undergraduate students believes more that instructors display democratic attitudes and behaviors less.

According to the monthly income of family variable, less participation is made on the view that teachers show democratic classroom management attitude as income level increases. However, according to education level of mother, the students whose mothers have associate degree and above indicate less participation regarding that teachers show democratic classroom management attitude compared to the students whose mothers have lower level education. Similarly, it was found that based on the education level of father, compared with the students whose fathers are secondary school graduates, the students whose fathers have associate degree and above make less participation for the view that teachers adopt democratic classroom management attitude. This situation can be considered as a result of the fact that as socio-economic level of family increases, democratic life expectancy in each area rises along with the awareness related to individual rights and freedoms. On the other hand, in their studies, Ergün and Kamer (2009) found that educational background of mother and father and profession of father do not affect the views of students.

The results of the research have also shown that the critical thinking dispositions of students are at high level. This is considered to be a positive situation for students since it is indicated that making the most pointed preference by individuals through evaluating right and wrong is possible with critical thinking (Padmaraju, 2006). There are similar studies that have yielded same results in the literature (Kalkan, 2008, p. 66). Contrary to this finding, while Demir and Aybek (2014) who conducted research with high school students in various educational stages (Ersoy \& Başer, 2011; Kahraman, 2008, p. 90) found that critical thinking dispositions of students are at low level whereas Baydar (2012) found that it is at moderate level.

Another finding of the research is that the critical thinking disposition of female students is higher than that of male students. It can be said that this situation results from the biological differences of being male and female. Besides, there are studies suggesting that biological differences of female and male individuals effect cognitive features (Fausto-Streling, 1944; Kimura, 1987). Sternberg's (1997, p. 102) idea suggesting that men comply with laws, they are sincere and liberal while women are manager (administrator), critical, external, and have conservative thinking style also explain this finding. In the literature, there are studies with similar results (Baydar, 2012, p. 84; Kalkan, 2008, p. 66; Yıldırım-Ankaralıgil, 2009, p. 83) and different results (Çekin, 2013; Demir \& Aybek, 2014; Kahraman, 2008, p. 91).

In the study, it was found that there are no differences in the critical thinking dispositions of the students in terms of grade level, monthly income of their families, and educational background of their parents. Similar to this study, Demir and Aybek (2014) and Kaloç (2005, p. 98-99) concluded that critical thinking dispositions do not vary in terms of education level of parents. There are also studies having found that as education level of the parents rise, students' critical dispositions also increase (Ay, 2006; Bilgiç \& Kurtuluş-Tosun, 2016; Çekin, 2013; Tümkaya \& Aybek, 2008). In parallel with this research, in the study conducted with 6th, 7th and 8th grade students, Ersoy and Başer (2011) concluded that no difference exists according to grade level. Kalkan (2008) also reported that as grade level goes up, students' critical thinking dispositions also increase.

On the basis of monthly income level of family variable, there are not any changes in critical thinking dispositions of the students. Accordingly, it was found that the critical thinking dispositions of students whose families have low monthly income are more than the students whose families have higher monthly income level. The studies having results similar to this finding are present in the literature (Bilgiç \& Kurtuluş-Tosun, 2016). However, contrary to this finding, there are studies having found that critical thinking dispositions or skills increase as income level increases and there are studies determining that critical thinking dispositions of students do not vary according to income level (Ay, 2006; Cheung, Rudowicz, Lang, Yue \& Kwan, 2001; Çekin, 2013; Pascarella, 1987; Tümkaya \& Aybek, 2008).

Another finding of the research is that there is a low, positive and significant relationship between the views of the students about the democratic classroom management attitudes of teachers and their critical thinking dispositions. More clearly, the democratic environment that teachers form in the class enhances the critical thinking dispositions of students. However, it was found that the views of the students about the democratic classroom management attitude of their teachers count for $7 \%$ of the variability in their critical thinking dispositions.

\section{Suggestions}

It is concluded in the study that the democratic classroom management attitudes of teachers are at moderate level according to the views of the students. This is considered to be inadequate to improve the critical thinking dispositions of students. Therefore, teachers should be supported to show more attention to display democratic attitudes and behaviors in classroom management. Another finding in this research is the lack of difference in the views of the students about the democratic classroom management attitude of their teachers according to gender. However, statistically significant differences are seen in students' views in terms of other variables. Accordingly, it is concluded 
that as the level of grade, monthly income of families and education level of parents increase, students find democratic classroom management attitudes of teachers less democratic. As the level of grade goes up, the interests, needs and expectations of students also vary. Therefore, it is expected that teachers should also display attitudes and behaviors appropriate for development level of each student. Low views of the students whose families have good socio-economic level can be a result of high democratic life expectancy and their attitude towards rights and freedoms as mentioned in discussion as well. Thus, the awareness of the students whose families have low socio-economic status should be raised on these issues. It could be thought that the students who develop awareness on their own rights and freedoms can be a driving power for displaying democratic classroom management by teachers. It is found in the study that the difference in the critical thinking dispositions of students exists only for gender and monthly income of families. Accordingly, it is concluded that the critical thinking dispositions of female students and the ones whose families have low monthly income are higher.

The results obtained in the study indicate that the democratic classroom management attitudes displayed in classrooms by teachers enhances the critical thinking dispositions of students which bring important duties and responsibilities to teachers. Furthermore, it is emphasized that students display behaviors such as asking question, critical thinking, and etc. in democratic and free learning environments (Morrison, 2008; O'Brien, 2005). In this regard, teachers are expected to create a democratic environment where students can express themselves freely and clearly. With the aim of providing incentive for displaying democratic classroom management attitudes by teachers, the trainings that stress the importance of this subject may be given. Furthermore, with various activities that teacher can perform together with students, adoption of democratic classroom management by students and teachers can be achieved.

This research is limited to 530 high school students studying at schools located in Altındağ, Ankara in the spring semester of 2013-2014 academic year. A corresponding study can be conducted with larger working groups from different regions in the same education stage. Furthermore, it is considered that reviewing the relationship between the critical thinking dispositions of students and the democratic classroom management attitudes of instructors at undergraduate level can make contributions to field. Democratic classroom management has an effect on critical thinking even a little. With other studies to be carried out, the roles of the variables that will become more efficient on the critical thinking dispositions of students can be analyzed.

\section{Acknowledgements}

A part of this paper was presented at the 4th International Symposium of Policies and Issues on Teacher Education held in Hacettepe University between 15 and 16 May 2014.

\section{References}

Akbıyı, C. (2002). Critical thinking dispositions and academic achievement (Unpublished master thesis). Hacettepe University, Ankara.

Ananiadou, K., \& Claro, M. (2009). 21st century skills and competences for new millennium learners in OECD countries. OECD Education Working Papers, No. 41, OECD Publishing. http://dx.doi.org/10.1787/218525261154

Assor, A., Kaplan, H., Kanat-Maymon, Y., \& Roth, G. (2005). Directly controlling teacher behaviors as predictors of poor motivation and engagement in girls and boys: The role of anger and anxiety. Learning and Instruction, 15(5), 397-413. http://dx.doi.org/10.1016/j.learninstruc.2005.07.008

Ay, Ş. (2006). The ability of critical thinking, educational background of parents and the monthly income of the family. Abant İzzet Baysal Üniversitesi Eğitim Fakültesi Dergisi, 6(2), 176-186.

Balay, R., Kaya, A., \& Doğu, Z. (2012). Secondary school students staying in a boarding house and their relationship with teacher. Elektronik Sosyal Bilimler Dergisi, 11(42), 103-128.

Baydar, S. (2012). Critical thinking dispositions of high school students according to their learning styles (Unpublished master thesis). Dokuz Eylül University, İzmir.

Beetham, D., \& Boyle, C. K. (1998). Introducing democracy: 80 questions and answers. (A. Z. Kopuzlu, Trans.). Ankara: Liberte.

Bellanca, J. A., \& Brandt, R. (Ed.). (2010). 21st century skills: Rethinking how students learn. Bloomington: Solution Tree Press.

Beyer, B. K. (1985). Critical thinking: What is it? Social Education, 49(4), 270-276.

Bilgiç, Ş., \& Kurtuluş-Tosun, Z. (2016). First and last grade nursing students' levels of critical thinking and affecting factors. Sağllk Bilimleri ve Meslekleri Dergisi, 3(1), 39-47. http://dx.doi.org/10.17681/hsp.00992

Büyükdüvenci, S. (1990). Demokrasi, eğitim ve Türkiye. Ankara Üniversitesi Eğitim Bilimleri Fakültesi Dergisi, 23(2), 


\section{3-597. http://dx.doi.org/10.1501/egifak_0000000771}

Byrne, B. M., \& Campbell T. L. (1999). Cross-cultural comparisons and the presumption of equivalent measurement and theoretical structure: A look beneath the surface. Journal of Cross Cultural Psychology, 30(5), 555-574. http://dx.doi.org/10.1177/0022022199030005001

Campbell, D. E. (2009). Choosing democracy: A practical guide to multicultural education (4th Edition). Cambridge: Pearson.

Çekin, A. (2013). The examination of critical thinking skills of religious culture and ethics teacher candidates in terms of some variables. Review of the Faculty of Divinity of Amasya University, 1(1), 25-46.

Çevik, S. (2013). An investigation of the critical thinking dispositions of preservice teachers at a private non-profit university (Unpublished master thesis). Bilkent University, Ankara.

Cheung, C. K., Rudowicz, E., Lang, G., Yue, X. D., \& Kwan, A. S. (2001). Critical thinking among university students: Does the family background matter? College Student Journal, 35(4), 577-598.

Demir, M. K. (2006). The research of fourth and fifth grade primary school students' critical thinking levels in social studies lessons according to different variables. Gazi Üniversitesi Gazi Ĕ̈itim Fakültesi Dergisi, 26(3), 155-169.

Demir, R., \& Aybek, B. (2014). An analysis of the critical thinking dispositions of high school students through various parameters. Muğla Sitkı Koçman Üniversitesi Sosyal Bilimler Enstitüsü Dergisi, (32), 122-140.

Demirkaya, H. (2008). Using critical thinking strategies and inquiry learning in geography instruction. Türkiye Sosyal Araştırmalar Dergisi, 12(1), 89- 116.

Demirtaş, H. (2004, Temmuz). Demokratik sınıf yönetimi ve üniversite ögrrencilerinin öğretim elemanlarının sınıf yönetimi tutum ve davranışlarına ilişkin görüssleri. Paper presented at the meeting of XIII. Ulusal Eğitim Bilimleri Kurultayı, Malatya, Turkey.

Dewey, J. (1991). Democracy and educational administration. Planning and Changing, 22, 134-140.

Duman, T., \& Koç, G. (2004, Temmuz). Eğitim fakültesi öğrencilerinin öğretim elemanlarının demokratik tutum ve davranışlarına ilişskin görüşleri. Paper presented at the meeting of XIII. Ulusal Eğitim Bilimleri Kurultayı, Malatya, Turkey

Emir, S. (2012). Eğitim fakültesi öğrencilerinin eleştirel düşünme eğilimleri. Hasan Ali Yücel Eğitim Fakültesi Dergisi, 17(1), 34-57.

Ennis, R. H. (1985). A logical basis for measuring critical thinking skills. Educational Leadership, 43(2), 44-48.

Erdem, A. R., \& Sarıtaş, E. (2006). Sınıf öğretmenliği öğrencilerinin öğretim elemanlarının davranışlarının demokratikliğine ilişkin algıları (PAÜ Örneği). Selçuk Üniversitesi Sosyal Bilimler Enstitüsü Dergisi, (16), 525-538.

Ergün, M., \& Kamer, S. T. (2009, Mayıs). Üniversite öğretim elemanlarının sınıf yönetimi tutum ve davranışlarına ilişkin sınıf öğretmenliği öğrencilerinin görüşleri (Kastamonu İli Örneği). Paper presented at the meeting of 8 . Ulusal Sınıf Öğretmenliği Sempozyumu, Eskişehir, Turkey

Ersoy, E., \& Başer, N. (2011). The position of critical thinking in elementary second stage. Adnan Menderes Üniversitesi Ĕgitim Fakültesi Eğitim Bilimleri Dergisi, 2(1), 1-10.

Esquivel, G. B. (1995). Teacher behaviors that foster creativity. Educational Psychology Review, 7(2), 185-202. http://dx.doi.org/10.1007/BF02212493

Fausto-Sterling, A. (2008). Myths of gender: Biological theories about women and men. Basic Books: New York.

Fisher, R. (2005). Teaching children to think. Nelson Thornes: Cheltenham.

Glaser, E. M. (1985). Critical thinking: Educating for responsible citizenship in a democracy. Phi Kappa Phi Journal, 65(1), 24-27.

Gorham, J., \& Christophel, D. M. (1992). Students' perceptions of teacher behaviors as motivating and demotivating factors in college classes. Communication Quarterly, 40(3), 239-252. http://dx.doi.org/10.1080/01463379209369839

Gürkaynak, İ., Üstel, F., \& Gülgöz, S. (2008). Eleştirel düşünme (ERG Reports, 3. Edition). İstanbul: Eğitim Reformu Girişimi. Retrieved from

http://www.egitimreformugirisimi.org/sites/www.egitimreformugirisimi.org/files/Elestireldusunme_0.pdf

Hashimoto, N., \& Fukuda, S. (2011). Reaching for their own goals: A more democratic classroom. The Language 
Teacher, 35(1), 17-22.

Hu, L., \& Bentler, P. M. (1999). Cut off criteria for fit indexes in covariance structure analysis: Conventional criteria versus new alternatives. Structural Equation Modeling: A Multidisciplinary Journal, 6(1), 1-55. http://dx.doi.org/10.1080/10705519909540118

Kahraman, T. (2008). Analysing the relation between 4th and 5th grade students' critical thinking abilities and the teachers' democratic behavior levels in the according to students' perception classroom (Unpublished master thesis). Marmara University, İstanbul.

Kalkan, G. (2008). Critical thinking levels of the seventh and eighth grade students (Unpublished master thesis). Eskişehir Osmangazi University, Eskişehir.

Kaloç, R. (2005). Critical thinking skills of students in secondary education institution and effective factors of critical thinking skills (Unpublished master thesis). Gazi University, Ankara.

Karadüz, A. (2010). Dil becerileri ve eleştirel düşünme. Turkish Studies, 5(3), 1566-1593.

Karbalaei, A. (2012). Critical thinking and academic achievement. İkala, Revista de Lenguaje y Cultura, 17(2), 121-128.

Kaya, H. İ., Taşdan, M., Kop, Y., \& Metin, M. (2012). The perceptions of the prospective teachers about the democratıc attitudes of the teaching staffs (city of Kars case). Pegem Ĕ̈itim ve Ögretim Dergisi, 2(1), 39-50.

Kesici, Ş. (2008). Teachers' opinions about building a democratic classroom. Journal of Instructional Psychology, 35(2), 192-204.

Kimura, D. (1987). Are men's and women's brains really different? Canadian Psychology, 28(2), 133-147. http://dx.doi.org/10.1037/h0079885

Kline, R. B. (2005). Principles and practice of structural equation modeling (2nd ed.). New York: Guilford Press.

Kocoska, J. (2009). The student's position in the democratic classroom. Procedia Social and Behavioral Sciences, 1(1), 2429-2431. http://dx.doi.org/10.1016/j.sbspro.2009.01.427

Korkmaz, Ö., \& Yeşil, R. (2009). Students' critical thinking level as to educational degrees. Ahi Evran Üniversitesi Kırşehir Eğitim Fakültesi Dergisi, 10(2), 19-28.

Kurt, A. A., \& Kürüm, D. (2010). Relationship between media literacy and critical thinking: A conceptual view. Mehmet Akif Ersoy Üniversitesi Sosyal Bilimler Enstitüsü Dergisi, (2), 20-34.

Leblanc, P. R., \& Skaruppa, C. (1997). Support for democratic schooling: classroom level change via cooperative learning. Action in Teacher Education, 19(1), 28-38. http://dx.doi.org/10.1080/01626620.1997.10462851

Lee, K. S. (2015). The effect of critical thinking skill on higher order critical thinking and academic achievement. Theory and Research in Citizenship Education, 47(3), 123-145.

Lewin, K. (1939). Field theory and experiment in social psychology: Concepts and methods. American Journal of Sociology, 868-896. http://dx.doi.org/10.1086/218177

Lipman, M. (1988). Critical thinking: What can it be? Educational Leadership, 46(1), 38-43.

Morrison, K. A. (2008). Democratic classrooms: Promises and challenges of student voice and choice. Educational Horizons, 87(1), 50-60.

Nanney, B. (2004). Student-centered learning. Retrieved from www.gsu.edu/ mstswh/courses/it7000/papers/student-.htm

Noone, C., Bunting, B., \& Hogan, M. J. (2016). Does mindfulness enhance critical thinking? Evidence for the mediating effects of executive functioning in the relationship between mindfulness and critical thinking. Frontiers in Psychology, 6, 1-16. http://dx.doi.org/10.3389/fpsyg.2015.02043

O'Brien, L. M. (2005). Social foundations of education and democracy: Teacher education for the development of democratically-oriented teachers. The Journal of Educational Foundations, 19(3/4), 33-44.

OECD (2013). The Skills Needed for the 21st Century. (OECD Report). Retrieved from http://dx.doi.org/10.1787/9789264204256-5-en

Özdemir, S. M. (2005). Üniversite öğrencilerinin eleştirel düşünme becerilerinin çeşitli değişkenler açısından değerlendirilmesi. Türk Ĕgitim Bilimleri Dergisi, 3(3), 297-316.

Padmaraju, K. (2006). Why critical thinking? Eastern Education Journal, 35(1), 61-64. 
Pascarella, E. T. (1987, Kasım). The development of critical thinking: Does college make a difference? Paper presented at the Annual Meeting of the Association for the Study of Higher Education, Baltimore.

Paul, R. W. (1984). Critical thinking: Fundamental to education for a free society. Educational Leadership, 42(1), 4-14.

Paul, R., \& Elder, L. (2007). The miniature guide for critical thinking: Concept and tools. The Foundation of Critical Thinking. Retrieved from http://www.duluth.umn.edu/ jetterso/documents/CriticalThinking.pdf

Pryor, C. R. (2004). Creating a democratic classroom: Three themes for citizen teacher reflection. Kappa Delta Pi Record, 40(2), 78-82. http://dx.doi.org/10.1080/00228958.2004.10517293

Rainer, J., \& Guyton, E. (1999). Democratic practices in teacher education and the elementary classroom. Teaching and Teacher Education, 15, 121-132. http://dx.doi.org/10.1016/S0742-051X(98)00039-0

Salpeter, J. (2003). 21 st century skills: Will our students be prepared? Technology and Learning-Dayton, 24(3), 17-29.

Schafersman, S. D. (1991). An introduction to critical thinking. Retrieved from http://facultycenter.ischool.syr.edu/wp-content/uploads/2012/02/Critical-Thinking.pdf.

Scriven, M., \& Paul, R. (2004). The critical thinking community. Retrieved from http://www.criticalthinking.org/pages/defining-critical-thinking/766

Semerci, Ç. (2011). Relationships between achievement focused motivation and critical thinking. African Journal of Businness Management, 5(15), 6180-6185.

Şentürk, İ., \& Oyman, N. (2014). Democratic classroom management in higher education: A qualitative study. Educational Sciences: Theory \& Practice, 14(3), 940-945.

Sternberg, R. J. (1986). Critical thinking: Its nature, measurement, and improvement. (ERIC Document Reproduction Service No. ED 272 882)

Sternberg, R. J. (1997). Thinking styles. Cambridge University Press: ABD. http://dx.doi.org/10.1017/CBO9780511584152

Ten Dam, G., \& Volman, M. (2004). Critical thinking as a citizenship competence: Teaching strategies. Learning and Instruction, 14(4), 359-379. http://dx.doi.org/10.1016/j.learninstruc.2004.01.005

Trilling, B., \& Fadel, C. (2009). 21 st century skills: Learning for life in our times. New York: John Wiley \& Sons.

Tümkaya, S., \& Aybek, B. (2008). Üniversite öğrencilerinin eleştirel düşünme eğilimlerinin sosyo-demografik özellikler açısından incelenmesi. Ç.Ü. Sosyal Bilimler Enstitüsü Dergisi, 17(2), 387-402.

Villavicencio, F. T. (2011). Critical thinking, negative academic emotions and achievement: A mediational analysis. The Asia-Pacific Education Researcher, 20(1), 118-126.

Wraga, W. G. (1998, Ağustos). Democratic leadership in the classroom: Theory into practice. Paper presented at the meeting of Czech National Civic Education Conference, Olomouc. Retrieved from http://eric.ed.gov/?id=ED427998

Wright, C. J., \& Nuthall, G. (1970). Relationships between teacher behaviors and pupil achievement in three experimental elementary science lessons. American Educational Research Journal, 7(4), 477-491. http://dx.doi.org/10.3102/00028312007004477

Yalçın, G. (2007). Teachers' and students' views about the democratic value of classroom management behaviours of high school teachers (Unpublished master thesis). İnönü University, Malatya.

Yalçın-Durmuş, G., \& Demirtaş, H. (2009). Teachers' and students' views about the high school teachers' democratic classroom management behaviors. Ondokuz Mayıs Üniversitesi Ĕgitim Fakültesi Dergisi, 28(1), 121-138.

Yıldırım-Ankaralıgil, S. (2009). A research on media literacy and critical thinking of 6th and 7th classes' students in elementary school (Unpublished master thesis). İstanbul University, İstanbul, Turkey.

This work is licensed under a Creative Commons Attribution 3.0 License. 